\title{
Situational Crime Prevention: A Study in Indian Context
}

\author{
Dr. Nirpat Patel ${ }^{1}$
}

\begin{abstract}
Situational Crime Prevention [also known as SCP]is a new crime prevention technique used in the field of Criminology and Criminal justice System in this paper author tried to explain the various applications of SCP. Situational crime prevention is a crime prevention strategy that addresses specific crimes by managing, designing and manipulating the environment in a manner that seeks to increase the risk to the offender, while reducing the offender's potential reward for committing the crime. 'Situational Crime Prevention' (SCP) is the name given by criminologists to crime prevention strategies that are aimed at reducing the criminal opportunities which arise from the routines of everyday life. Such strategies include 'hardening' of potential targets, improving surveillance of areas that might attract crime (e.g. closed circuit television surveillance), and deflecting potential offenders from settings in which crimes might occur (e.g., by limiting access of such persons to shopping malls and other locales). While there has been much research and criminological discussion of SCP, it has focused on issues of effectiveness and other technical aspects e.g., does closed-circuit television $(C C T V)$ surveillance 'work', in the sense of deterring offenders or aiding in the detection of offences? The larger issues especially the ethical ones were little addressed. Situational crime prevention is a primary prevention measure. This means that it is directed at stopping crime problems before they occur. Like other primary crime prevention measures, situational prevention tends to focus on reducing crime opportunities rather than on the characteristics of criminals or potential criminals.
\end{abstract}

Keywords: Situational Crime Prevention, Environmental Criminology, Rational Choice Theory, Routine Activity Theory, CJS and Scene of Crime.

\section{Introduction of Situational Crime Prevention [SCP]}

'Situational Crime Prevention' (SCP) is the name given by criminologists to crime prevention strategies that are aimed at reducing the criminal opportunities which arise from the routines of everyday life. Such strategies include 'hardening' of potential targets, improving surveillance of areas that might attract crime (e.g. closed circuit television surveillance), and deflecting potential offenders from settings in which crimes might occur (e.g., by limiting access of such persons to shopping malls and other locales). While there has been much research and criminological discussion of SCP, it has focused on issues of effectiveness and other technical aspects e.g., does closed-circuit television (CCTV) surveillance 'work', in the sense of deterring offenders or aiding in the detection of offences? The larger issues especially the ethical ones were little addressed. Situational crime prevention is a primary prevention measure. This means that it is directed at stopping crime problems before they occur. Like other primary crime prevention measures, situational prevention tends to focus on reducing crime opportunities rather than on the characteristics of criminals or potential criminals.

Situational prevention seeks to reduce opportunities for specific categories of crime by increasing the associated risks and difficulties and reducing the rewards. It comprises three main elements:

1. an articulated theoretical framework;

2. a standard methodology for tackling specific crime problems; and

3. a set of opportunity-reducing techniques.

Situational crime prevention is an approach that encompasses a wide range of practical and common sense thinking about crime and its prevention. It reflects the everyday strategies that individuals and organizations use to protect themselves and their property.

\section{Concept of SCP}

Situational crime prevention is a crime prevention strategy that addresses specific crimes by managing, designing and manipulating the environment in a manner that seeks to increase the risk to the offender, while reducing the offender's potential reward for committing the crime.

Origin of the Approach

The Approach of Situational Crime Prevention [SCP] came in the existence in India due to the virtual failures of existing Criminal Justice Agencies [CJAs] in bringing the crime rate down to the optimum level of public satisfaction.

${ }^{1}$ Guest Lecturer at Department of Criminology \& Forensic Science, Dr. Harisingh Gour Central University, Sagar [M. P.] 


\section{What is SCP?}

1. SCP is a new approach that encompasses a wide range of practical thinking about the crime and its prevention.

2. SCP is a crime prevention strategy that addresses specific crimes by managing, designing and manipulating the environment in a manner that seeks to increase the risk to the offender, while reducing the offender's potential reward for committing the crime.

\section{Statement of Problem}

The present study intends to examine the notion of situational crime prevention. The idea is to analyze the opportunity theory and various measures of crime reduction. The exercise mainly aims of identifying the presence of situational element in certain crimes against property thereby exploring the possibility of framing SCP measure in Indian context. With the help of a sample survey, the present study highlights the factors and combinations making the targets situationally vulnerable for crime. A critical review of concept and theoretical structure pertaining to SCP is also proposed to be undertaken.

\section{Objectives}

1. To assess the extent and type of crimes that could be attributed to the ten principles of opportunity developed by R V Clarke.

2. To explore the situational dimensions attributable to the occurrence of crime in the selected sites.

3. To consider the opportunity theory model in case of selected types of crimes.

4. To assess the situational attributes in crime occurrence with the help of the perceptions of crime victims

5. To assess the efficacy of situational crime prevention tools in crime reduction and local security needs.

6. To develop a situational crime prevention training module for law enforcement agencies and security personnel.

\section{Importance of SCP}

1. Reduces the opportunities for criminals to commit crime

2. Changes criminals' ideas about whether they can get away with a particular crime

3. Makes it seem harder, riskier, and less rewarding to commit crime

\section{The Change in Thinking}

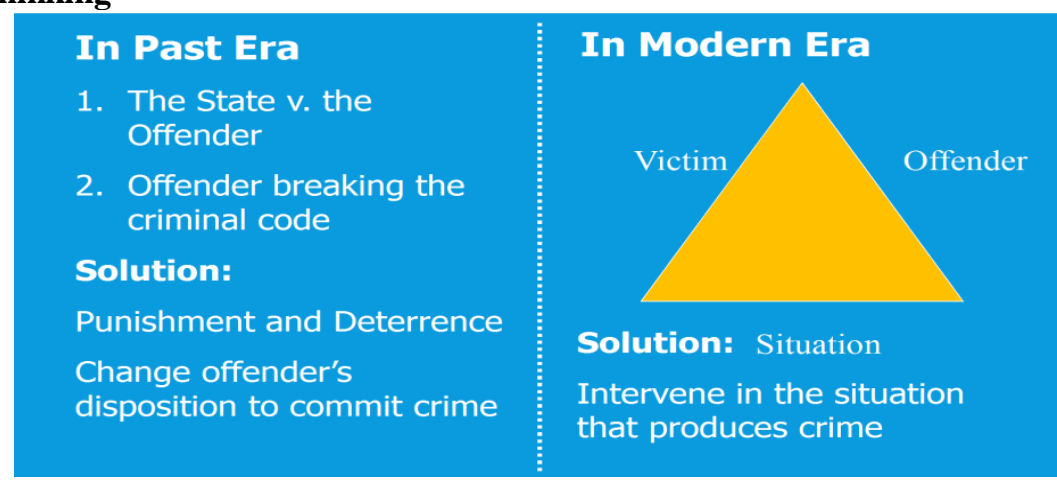

\section{Theories that Assists SCP Approach}

1. Environmental Criminology

2. Rational Choice

3. Routine Activity

\section{Environmental Criminology}

Crime happens when four things come together: a law, an offender, a victim or target, and a place. Environmental criminologists examine the fourth element -- place (and the time when the crime happened).

\section{Rational Choice}

Rational Choice theory says that criminals think about their decisions before they commit crime. In other words, people don't commit crimes because of forces beyond their control. Criminals commit crime because they benefit from it. The benefits of committing crime are greater than the benefits of not committing crime. 


\section{Routine Activity}

The routine activity approach says that in order for a crime to happen there must be three things -- an offender likely to commit a crime, a suitable target, and no one watching this target. If one of the three things is removed, there will be no crime.

\section{Routine Activities Theory}

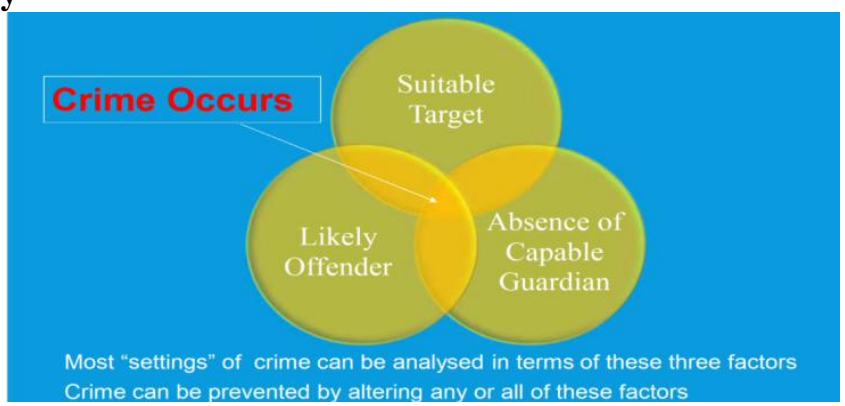

\section{Situational Approach to Theft Cases-}

Table 1.1: Frequency distribution of Scene of crime

\begin{tabular}{|l|c|c|c|}
\hline \multirow{2}{*}{ Scene of crime } & \multicolumn{2}{|c|}{ Study Area } & \multirow{2}{*}{ Total } \\
\cline { 2 - 4 } & Indore & Jabalpur & \\
\hline \multirow{3}{*}{ Theft from shop } & 8 & 12 & 20 \\
\cline { 2 - 4 } & $2.0 \%$ & $3.0 \%$ & $5.0 \%$ \\
\cline { 2 - 4 } & 2 & 2 & 4 \\
\hline Theft from business place & $.5 \%$ & $.5 \%$ & $1.0 \%$ \\
\hline Theft from vehicle & 57 & 65 & 122 \\
\cline { 2 - 4 } & $14.3 \%$ & $16.3 \%$ & $30.5 \%$ \\
\hline Vehicle's theft & 1 & 2 & 3 \\
\cline { 2 - 4 } & $.3 \%$ & $.5 \%$ & $.8 \%$ \\
\hline Others & 118 & 88 & 206 \\
\cline { 2 - 4 } & $29.5 \%$ & $22.0 \%$ & $51.5 \%$ \\
\hline Total & 14 & 31 & 45 \\
\cline { 2 - 4 } & $3.5 \%$ & $7.8 \%$ & $11.3 \%$ \\
\cline { 2 - 4 } & 200 & 200 & 400 \\
\hline
\end{tabular}

Table 1.1 presents the nature of scene of crime. It has been observed in the study that the highest percent of cases were of vehicle theft i.e. 51.5 percent, 29.5 percent is in Indore and 22 percent in Jabalpur. The lowest percent of cases were of theft from business places $(0.5$ percent $)$ in both the cities.

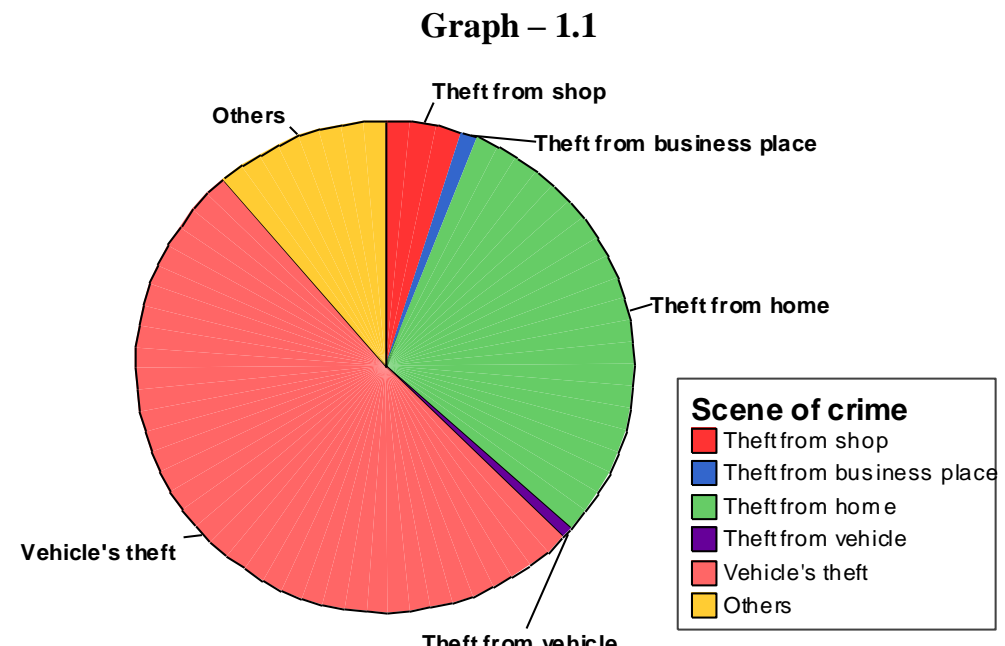


Table 1.2: Time of incidence

\begin{tabular}{|l|c|c|c|}
\hline \multirow{2}{*}{ Time of incidence } & \multicolumn{2}{|c|}{ Study Area } & \multirow{2}{*}{ Total } \\
\cline { 2 - 4 } & Indore & Jabalpur & 17 \\
\hline \multirow{2}{*}{ 12 to $11: 59$ AM $5: 59$ PM } & 14 & 3 & $4.3 \%$ \\
\cline { 2 - 4 } & $3.5 \%$ & 35 & 83 \\
\hline 6 to $11: 59$ PM & 48 & $8.8 \%$ & $20.8 \%$ \\
\cline { 2 - 4 } & $12.0 \%$ & 93 & 166 \\
\hline 12 to 5:59 AM & 73 & $23.3 \%$ & $41.5 \%$ \\
\cline { 2 - 4 } & $18.3 \%$ & 69 & 134 \\
\hline Total & 65 & $17.3 \%$ & $33.5 \%$ \\
\cline { 2 - 4 } & $16.3 \%$ & 200 & 400 \\
\hline
\end{tabular}

Table 1.2 denotes the time of occurrence in Indore and Jabalpur cities. It has been observed from the study that most of the incidences of theft occurred between 6 to $11.59 \mathrm{pm}$ in both the cities (41.5 percent; Indore 18.3 percent and Jabalpur 23.3 percent). While the lowest percent of incidences occurred between 6 to 11.59 am in these cities which was 4.3 percent i.e. Indore 3.5 percent and Jabalpur 0.8 percent respectively.

$$
\text { Graph }-1.2
$$

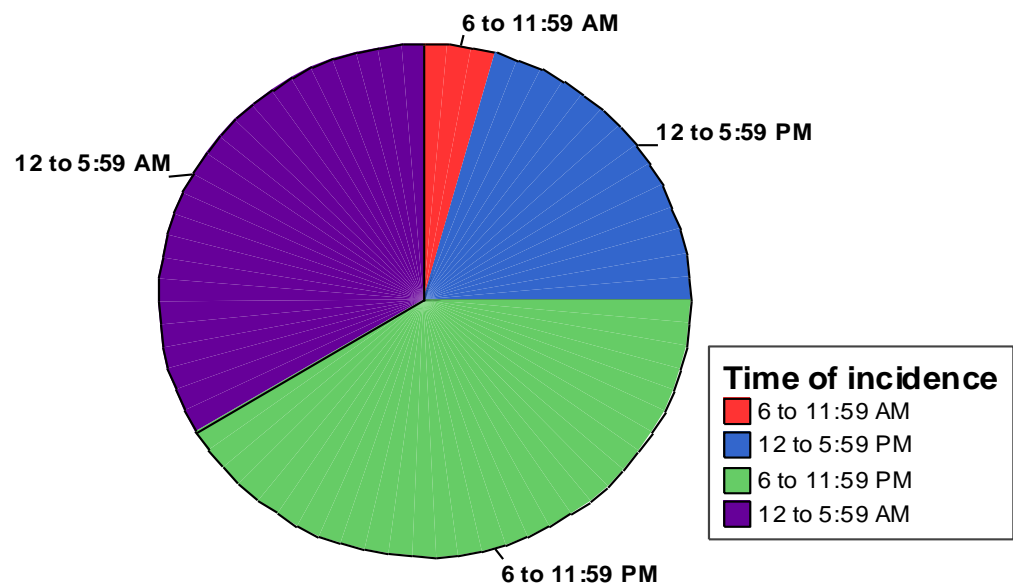

Table 1.3: Type of scene of crime

\begin{tabular}{|l|c|c|c|}
\hline \multirow{2}{*}{ Type of scene of crime } & \multicolumn{2}{|c|}{ Study Area } & \multirow{2}{*}{ Total } \\
\cline { 2 - 4 } & Indore & Jabalpur & \\
\cline { 2 - 4 } & 125 & 122 & 247 \\
\hline \multirow{2}{*}{ Oplose } & $31.3 \%$ & $30.5 \%$ & $61.8 \%$ \\
\cline { 2 - 4 } & 74 & 78 & 152 \\
\hline \multirow{2}{*}{ Mobile } & $18.5 \%$ & $19.5 \%$ & $38.0 \%$ \\
\cline { 2 - 4 } & 1 & 0 & $.3 \%$ \\
\hline \multirow{2}{*}{ Total } & $.3 \%$ & $.0 \%$ & 400 \\
\cline { 2 - 4 } & 200 & $50.0 \%$ & $100.0 \%$ \\
\hline
\end{tabular}

Table 1.3 shows that the type of scene of crime in the two cities. It has been observed from the study that the most cases of theft occurred in open places (61.8 percent in both the cities which was 31.3 percent in Indore and 30.5 percent in Jabalpur). 


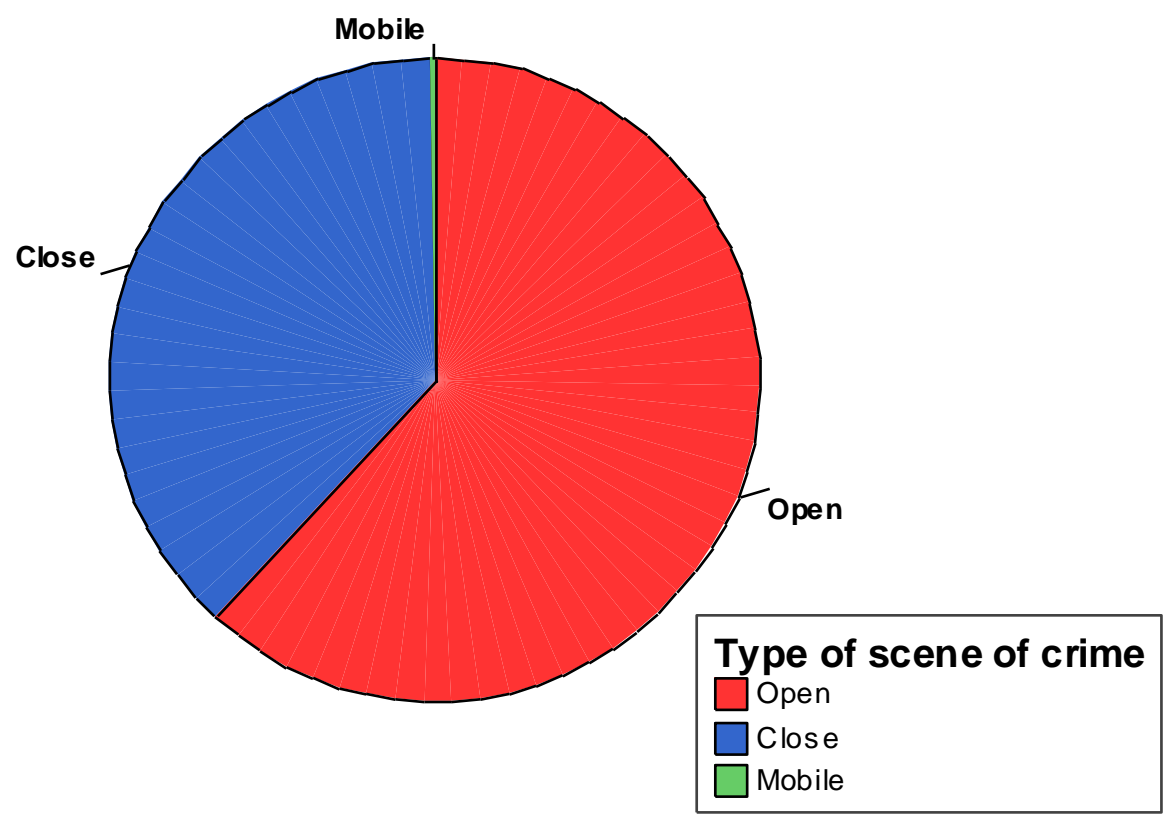

Table 1.4: Location of scene of crime

\begin{tabular}{|l|c|c|c|}
\hline \multirow{2}{*}{ Location of Scene of crime } & \multicolumn{2}{|c|}{ Study Area } & \multirow{2}{*}{ Total } \\
\cline { 2 - 4 } & Indore & Jabalpur & 125 \\
\hline \multirow{2}{*}{ Hot spot } & 88 & 37 & $31.3 \%$ \\
\cline { 2 - 4 } & $22.0 \%$ & $9.3 \%$ & 171 \\
\cline { 2 - 4 } & 72 & $24.8 \%$ & $42.8 \%$ \\
\cline { 2 - 4 } & $18.0 \%$ & 64 & 104 \\
\hline Tool spot & 40 & $16.0 \%$ & $26.0 \%$ \\
\cline { 2 - 4 } & $10.0 \%$ & 200 & 400 \\
\cline { 2 - 4 } & 200 & $50.0 \%$ & $100.0 \%$ \\
\hline
\end{tabular}

Table 1.4 shows that location of scene of crime in Indore and Jabalpur cities. It has been found from the study that the most of the incidences of theft occurred in semi-hotspot that (42.8 percent in which was 18 percent in Indore and 24.8 percent in Jabalpur. While 26 percent incidences of theft occurred in cool spots in both cities.

Table 1.5:Do the stolen goods have easy available market for selling

\begin{tabular}{|c|c|c|c|}
\hline \multirow{2}{*}{$\begin{array}{l}\text { Do the stolen goods have easily } \\
\text { available market for selling }\end{array}$} & \multicolumn{2}{|c|}{ Study Area } & \multirow{2}{*}{ Total } \\
\hline & Indore & Jabalpur & \\
\hline \multirow[t]{2}{*}{ No } & 10 & 0 & 10 \\
\hline & $2.5 \%$ & $.0 \%$ & $2.5 \%$ \\
\hline \multirow[t]{2}{*}{ Can't say } & 73 & 46 & 119 \\
\hline & $18.3 \%$ & $11.5 \%$ & $29.8 \%$ \\
\hline \multirow[t]{2}{*}{ Only some special places } & 26 & 20 & 46 \\
\hline & $6.5 \%$ & $5.0 \%$ & $11.5 \%$ \\
\hline \multirow[t]{2}{*}{ Outside the city } & 14 & 29 & 43 \\
\hline & $3.5 \%$ & $7.3 \%$ & $10.8 \%$ \\
\hline \multirow[t]{2}{*}{ Easily available } & 77 & 94 & 171 \\
\hline & $19.3 \%$ & $23.6 \%$ & $42.9 \%$ \\
\hline \multirow[t]{2}{*}{ Others } & 0 & 10 & 10 \\
\hline & $.0 \%$ & $2.5 \%$ & $2.5 \%$ \\
\hline \multirow[t]{2}{*}{ Total } & 200 & 199 & 399 \\
\hline & $50.1 \%$ & $49.9 \%$ & $100.0 \%$ \\
\hline
\end{tabular}

The data shown in Table 3.24 confirms that in 42.9 percent victims felt it that the stolen goods have easily available market in both the cities (in Indore 19.3 percent and in Jabalpur 23.6 percent). While 2.5 percent victims in Indore city they found there was no market to sell the stolen goods. 

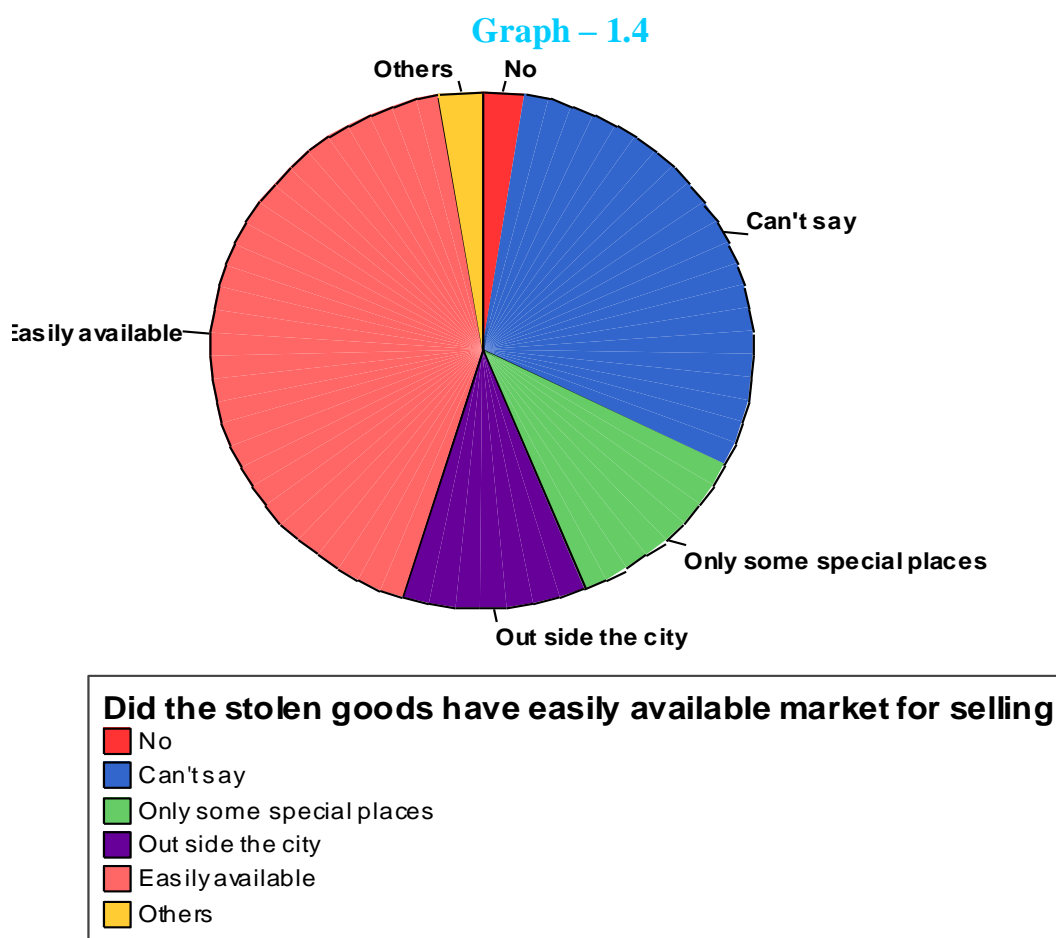

\section{SCP in Home Safety}

1. Get involved in your community i.e. crime watch.

2. Get to know yours neighbors.

3. Use deadbolt locks.

4. Don't hide your keys near homes.

5. Report any type suspicious activities to law enforcement agencies.

6. Supervise your Children.

7. Install high wattage bulbs on porch lights.

8. Check fire extinguishers and smoke alarms twice in a year.

9. Post emergency numbers by the phone.

10. Have a neighbor or friend look after your house.

11. Put your lights on times.

12. Stop all deliveries.

\section{SCP In Case of Vehicle Safety}

1. Install an alarm system with an ignition cut off switch and a hood locking device.

2. Roll windows up and lock your doors even if you are just running in for a minute.

3. Don't leave valuable things in the vehicle.

\section{Conclusive Remarks}

Some broad suggestions emerging out of the study can be summarized as below:

$\checkmark$ The situational crime prevention ought to be viewed as a dynamic application. The need to widen its approach and applications in the newer setting and crimes is therefore imperative.

$\checkmark$ SCP needs to be clearly located in the theoretical boundaries of criminological research. An attempt in this study has been made to this effect.

$\checkmark$ SCP needs to be tailored to respond other variety of crime. It can have applicability in cases of certain economic, violent crimes and terrorist crimes.

$\checkmark$ Almost no research exists as to whether SCP would work in the changing context or not. The most SCP practices were carried out and evaluated in case UK, USA or Australia. The applicability of SCP in developing countries, diversified regions, and relatively lesser techno-oriented societies etc. is yet to be explored.

$\checkmark$ SCP has many success stories in the UK and USA where the crimes rates have shown visible reduction due these measures.

$\checkmark$ The issue of sustainability of SCP in long term is also crucial.

$\checkmark \quad$ The personnel applying and evaluating SCP needs to have adequate training orientation. 


\section{References}

[1]. Abagnale, Frank W. (2002): The Art of the Steal: How to Protect Yourself and Your Business from Fraud, America's Crime: USA, Broadway

[2]. Adam Crawford, Crime Prevention and Community Safety: Politics, Policies and Practices (London: Longman, 1998).

[3]. Allen, J. 2000. Community survey of willingness to receive stolen goods Crime and Justice Bulletin No. 51, Sydney: NSW Bureau of Crime Statistics and Research.

[4]. Anderson D, Chenery S and Pease K (1994): Biting Back: Tackling repeat burglary and car crime, Crime Detection and Prevention Series Paper 58, London, Home Office.

[5]. Anderson, D. S. Chenery and K. Pease, 1995 Biting Back: Tackling repeat burglary and car crime. Crime Detection and Prevention Series Paper 58, London: Home Office.

[6]. Atkins, S., Husain, S. and Storey, A. (1991) The influence of street lighting on crime and fear of crime. Crime Prevention Unit Paper, No 28, London: Home Office. http://www.homeoffice.gov.uk/

[7]. Australian Institute of Criminology, 2005, The market reduction approach to reducing property crime. All Crime Matters 32. http://www.aic.gov.au/ (accessed 8 April 2005). Also available from Canberra: Australian Institute of Criminology.

[8]. Bennett, T. and L. Durie. 1999. Preventing residential burglary in Cambridge: From crime audits to targeted strategies. Crime Detection and Prevention Series Paper 108. London: Home Office.

[9]. Blake, L. and R. Coupe. 2001. The impact of single and two-officer patrols on catching burglars in the act. British Journal of Criminology 41 (2): 381-396.

[10]. Boyce, P. R., Elkland, N. H., Hamilton, B. J. and Bruno, L. D. (2000) Perceptions of safety at night in different lighting conditions. Lighting Research and Technology, 32(2), 79-91.

[11]. Brown, B. (1995) CCTV in town centres: three case studies. Crime Detection and Prevention Series, Paper 68, Police Research Group. London: Home Office. http://www.homeoffice.gov.uk/, or available through ICOLE (2002)

[12]. Bullock, Karen \&Tilley Nick (2003): Crime Reduction and problem Oriented Policing, Devon, UK Willan

[13]. Casey C. et al. and Segessenmann, T. 2003. Evaluation of the target hardening pilot programme. Wellington: Ministry of Justice.

[14]. Clarke R V (1999): Hot Products: understanding, anticipating and reducing demand for stolen goods Police Research Series Paper 112

[15]. Clarke RV (1997): 'Introduction' in RV Clarke (ed), Situational crime prevention: Successful case studies (2nd ed). Harrow and Heston: Guilderland, New York.

[16]. Clarke, R. V. \& Eck John (2003): Become a Problem- Solving Analyst,:Devon,UKWillanClarke, R. V. and M. Felson (Eds.) (1993). Routine Activity and Rational Choice. Advances in Criminological Theory, Vol 5. New Brunswick, NJ: Transaction Books.

[17]. Clarke, R. V. and Lester, D. (1989) Suicide: Closing the Exits. Springer- Verlag; New York.

[18]. Cohen, L.E. and M. Felson (1979): Social change and crime rate trends: a routine activity approach. American Sociological Review, Vol 44, Pages 588-608.

[19]. Cope, N. 2004, Intelligence-led policing or policing-led intelligence, Integrating volume crime analysis into policing. British Journal of Criminology 44 (2): 188-203.

[20]. Dean Southall and Paul Ekblom (1985): Designing for Car Security: Towards a Crime Free Car. London- Crime Prevention Unit Paper (Home Office).

[21]. Di Tella, R. and Schargrodsky, E. (2001) Using a terrorist attack to estimate the effect of police on crime. Draft, 2001-04-30.

[22]. http://www.people.hbs.edu/rditella/papers/using terrorist \%20attack.pdfHearnden, I and C Magill (2004) Decision-making by burglars: Offenders' perspectives. Home Office Findings 249, London: Home Office.

[23]. Williams, R. 2004. The management of crime scene examination in relation to the investigation of burglary and vehicle crime. Home Office Online Report 24/04. http://www.homeoffice.gov.uk/rds (accessed 27 March 2005).

[24]. Witte, A. D. and Witt, R. (2000) Crime causation: economic theories. (Preprint, 2000-07-19, Encyclopedia of Crime and Justice.) http://www.econ.surrey.ac.uk/WorkingPapers/econ300.pdf 